\title{
Pristomyrmex rasnitsyni sp.n., the first known fossil species of the ant genus Pristomyrmex Mayr (Hymenoptera: Formicidae) from the Late Eocene Danish Amber
}

\section{Pristomyrmex rasnitsyni sp.n. - первый известный ископаемый вид муравьев рода Pristomyrmex Mayr (Hymenoptera: Formicidae) из позднеэоценового датского янтаря}

\author{
G.M. Dlussky ${ }^{1}$, A.G. Radchenko \\ Г.М. Аиусский ${ }^{1}$, А.Г. Радченко
}

\footnotetext{
${ }^{1}$ Moscow State University, Faculty of Biology, Vorob’evy gory, Moscow 119899, Russia. E-mail: dlusskye@mail.ru

${ }^{1}$ Московский государственный университет, биологический факультет, Воробьевы горы, Москва 119899, Россия.

${ }^{2}$ Museum and Institute of Zoology, Polish Academy of Sciences, 64 Wilcza str., Warsaw 00-679, Poland. E-mail: agradchenko@hotmail.com

${ }^{2}$ Музей и Институт зоологии Польской Академии Наук, ул. Вильча, 64, Варшава 00-679, Польша.
}

KEY WORDS: Insecta, Hymenoptera, Formicidae, Myrmicinae, Myrmecinini, Pristomyrmex rasnitsyni, new species, Danish Amber, Late Eocene, palaeontology.

КЛЮЧЕВЫЕ СЛОВА: Insecta, Hymenoptera, Formicidae, Myrmicinae, Myrmecinini, Pristomyrmex rasnitsyni, новый вид, датский янтарь, поздний эоцен, палеонтология.

ABSTRACT. The ant species Pristomyrmex rasnitsyni sp.n. is described from the Danish Late Eocene Amber. This is the first record of the fossil member of the genus Pristomyrmex Mayr.

РЕЗЮМЕ. Муравей Pristomyrmex rasnitsyni sp.n. описан из Датского позднеэоценового янтаря. Это первая находка ископаемого представителя рода Pristomyrmex Mayr.

\section{Introduction}

The genus Pristomyrmex Mayr, 1866 belongs to the tribe Myrmecinini of the ant subfamily Myrmicinae. It comprises 57 extant species distributed mostly in the Oriental Region, while several endemic species occur in Central and partly South Africa, Australia, and islands of the Indian and Pacific Oceans. The only widely distributed species, P. punctatus (F. Smith, 1860), goes far to the North, i.e. to the Palaearctic Region through temperate China, Korean Peninsula and Japan to the southern part of Hokkaido Island, though it is absent from the Russian Far East (Fig. 1) [Wang, 2003; Zettel, 2006; Bolton et al., 2006; Terayama, 2009]. The majority of the species inhabit tropical rainforests, where they build nests in soil or in dead wood and forage as scavengers and predators in leaf litter, uopn the ground or on the trees.

Pristomyrmex has a combination of features that clearly distinguishes it from other members of the tribe Myrmecinini, namely: its workers are monomorphic; antennae have 11 segments; frontal lobes are absent or strongly reduced, vestigial and vertical, so that antennal sockets are fully exposed; propodeum, often also pronotum, with spines or at least long teeth (with the only known exception); petiole quite large, with long peduncle and high node with a rounded dorsum. On the contrary, workers of Perissomyrmex M. R. Smith, 1947 are polymorphic, and those of Acanthomyrmex Emery, 1893 dimorphic; antennae in Myrmecina Curtis, 1829 and Acanthomyrmex are 12-segmented, and in Perissomyrmex 9-segmented; frontal lobes in Myrmecina are well developed and at least partly cover antennal sockets; pronotum of Myrmecina and Perissomyrmex always without spines or teeth; in addition, petiole of Myrmecina is sessile, without an anterior peduncle.

No any fossil Pristomyrmex species was known until now. However, during an ongoing revision of ants from the European Late Eocene ambers we have found one worker that undoubtedly belonged to that genus. This species, described below as $P$. rasnitsyni sp.n., is the first known extinct member of the genus Pristomyrmex.

\section{Material and methods}

We investigated a piece of Danish amber, containing a single worker (holotype); it is preserved in the Zoological Museum of the University of Copenhagen, Denmark.

The figures are based on the original drawings of the specimens and photographs made using Olympus Camedia C-3030 digital camera fitted to Olympus SZX9 microscope in conjunction with the computer program CorelDraw 8. 


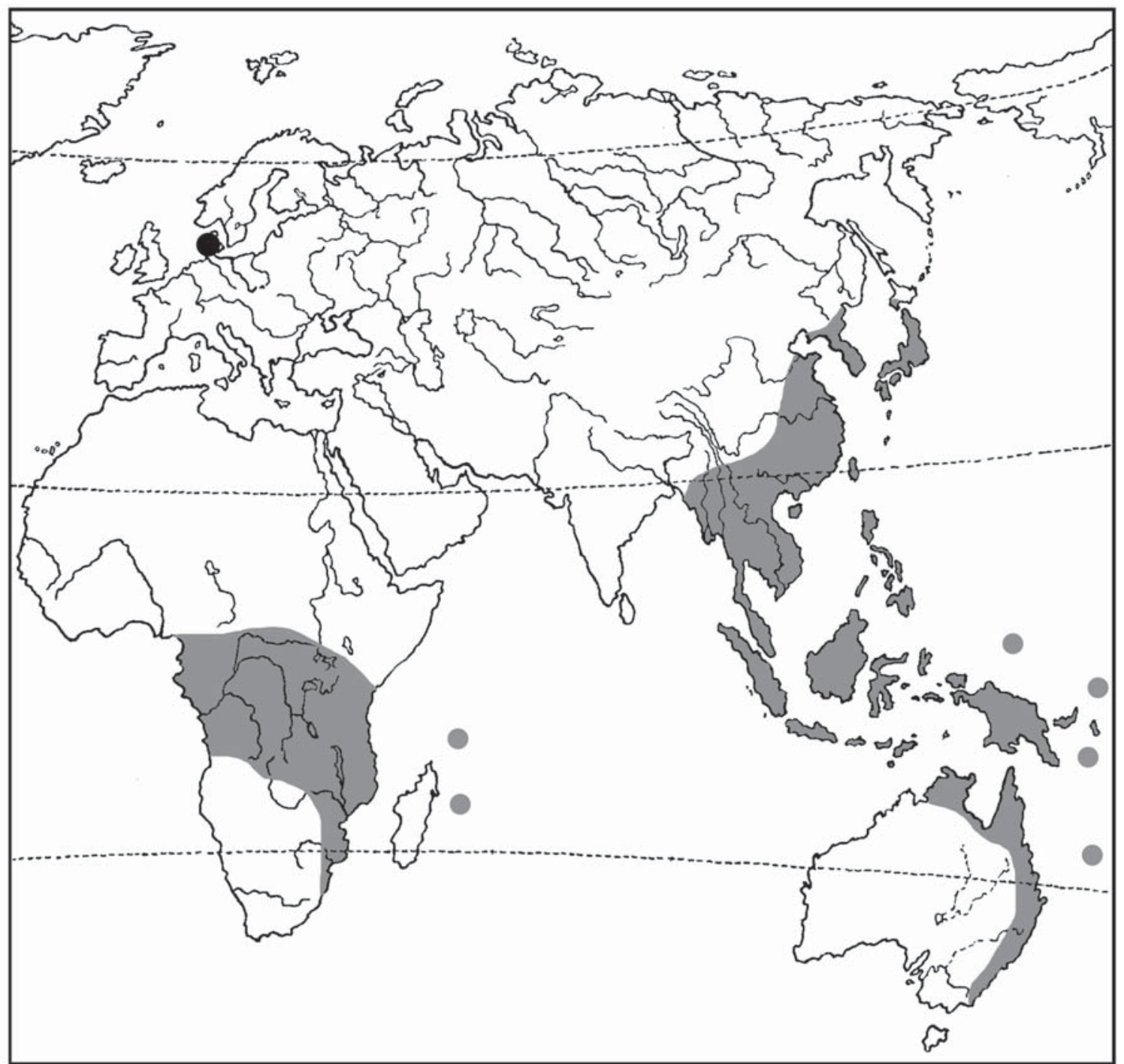

Fig. 1. Map of the modern distribution of the genus Pristomyrmex (gray filling and dots) and the site of fossil P. rasnitsyni in Denmark (black dot).

Рис. 1. Карта современного распространения рода Pristomyrmex (серая заливка и точки) и место нахождения ископаемого $P$. rasnitsyni в Дании (черная точка).

Morphometrics. The specimens were measured (up to $0.01 \mathrm{~mm}$ precision) using stereomicroscope Leica $\mathrm{S} 6 \mathrm{E}$, and the measurements were used to calculate various indices (see below). We measured as many features of the specimen as possible, given that not all of them could be easily seen and measured.

Measurements: AL — diagonal length of the mesosoma seen in profile, measured from the anterodorsal margin of pronotum to the posterior margin of propodeal lobes; ESL - maximum length of propodeal spine in profile, measured along the spine from its tip to the deepest point of the propodeal constriction at the base of the spine; ESD - distance between the tips of propodeal spine in dorsal view; FW - minimum width of frons between the frontal carinae; HL - length of head in full face view, measured as a straight line from the anterior point of median clypeal margin to midpoint of the posterior occipital margin (including clypeal teeth); HW - maximum width of head in full face view behind the eyes; HTL - length of tibia of the hind leg; OL - maximum diameter of eye; PnW maximum width of pronotum seen from above; PW maximum width of petiole seen from above; PPL maximum length of postpetiole seen from above; PPW maximum width of postpetiole seen from above; SL maximum straight-line length of antennal scape seen in profile.

Indices: $\mathrm{CI}=\mathrm{HL} / \mathrm{HW}$; ESLI $=\mathrm{ESL} / \mathrm{HW}$; ESDI = $\mathrm{ESD} / \mathrm{ESL} ; \mathrm{FI}=\mathrm{FW} / \mathrm{HW} ; \mathrm{HTI}=\mathrm{HTL} / \mathrm{HL} ; \mathrm{OI}_{1}=\mathrm{OL} /$ $\mathrm{HL} ; \mathrm{OI}_{2}=\mathrm{OL} / \mathrm{HW} ; \mathrm{PI}=\mathrm{PW} / \mathrm{HW} ; \mathrm{PPI}_{1}=\mathrm{PPW} / \mathrm{HW}$; $\mathrm{PPI}_{2}=\stackrel{\mathrm{PPW}}{\mathrm{P} W} ; \mathrm{SI}_{1}=\mathrm{SL} / \mathrm{HL} ; \mathrm{SI}_{2}=\mathrm{SL} / \mathrm{HW}$. 


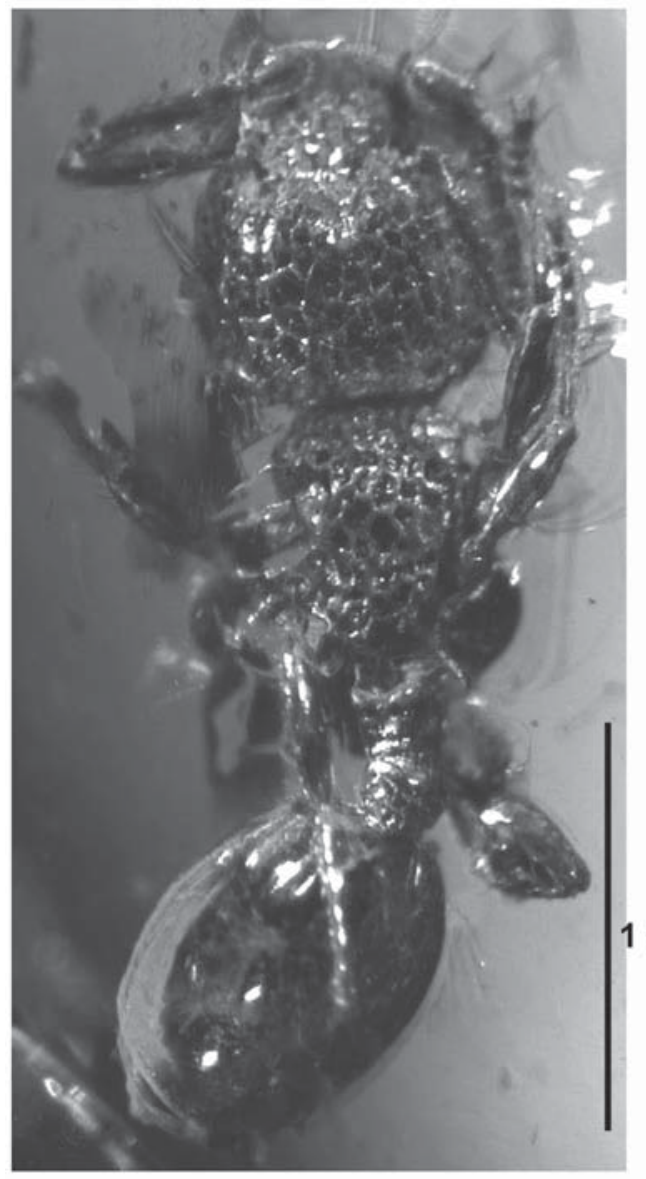

a

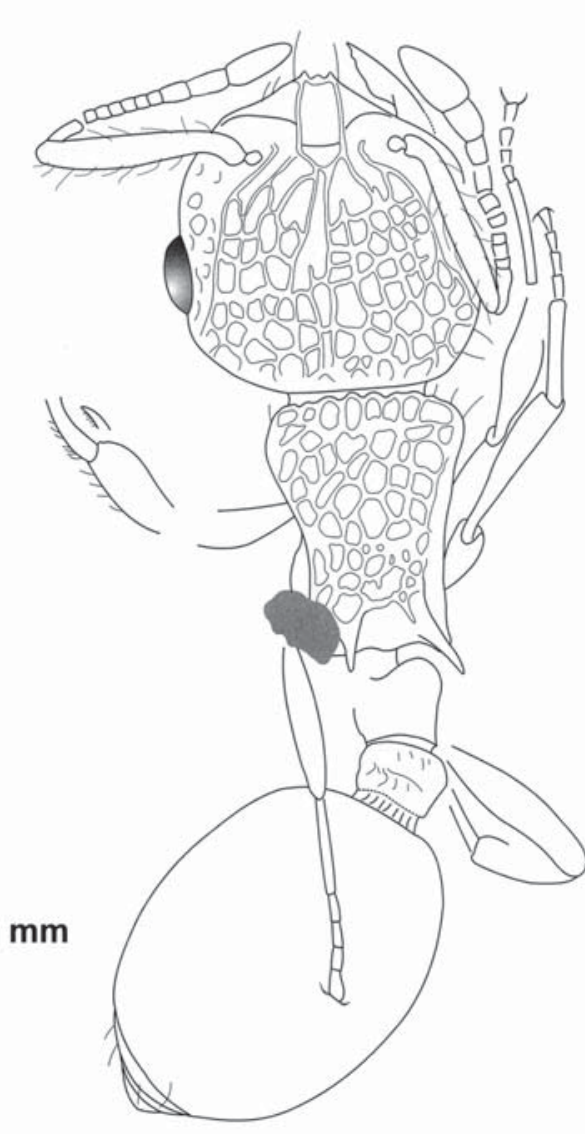

b

Fig. 2. Photograph of the holotype of worker P. rasnitsyni in dorsal view (a) and explanatory drawing of the same specimen in dorsal view (b).

Рис. 2. Фотография голотипа рабочего P. rasnitsyni, вид сверху (а), и прорисовка того же экземпляра, вид сверху (b).

\section{Taxonomic part}

\section{Pristomyrmex rasnitsyni sp.n.}

\section{Fig. 2.}

MATERIAL EXAMINED. Worker, holotype, leg. G.V. Henningsen, 1.ii.1969, Zoological Museum of the University of Copenhagen, No. 328.

DESCRIPTION. Worker. Head somewhat wider its length, with slightly convex sides, straight occipital margin and broadly rounded occipital corners. Anterior clypeal margin medially with two short blunt lateral teeth and one smaller central tooth. Frontal lobes vestigial, vertical; frons very narrow; antennal sockets fully exposed. Antennae 11-segmented, with distinct 3-segmented apical club; scape sharply angled at base, almost reaching occipital margin. Dentation of mandibles barely visible, but masticatory margin seems to have big apical and somewhat shorter preapical tooth, long diastema and very small blunt basal tooth.
Mesosoma short, promesonotum narrowed posteriorly, with rounded anterolateral corners and convex anterior margin, delineated anteriorly and laterally by carinae (seen from above). Metanotal groove distinct, very wide but shallow. Propodeal spines rather long, straight, quite blunt at the tip, directed backwards and upwards at an angle ca. $40^{\circ}$, strongly diverging. Pronotum without spines or teeth.

Petiole with long peduncle and strongly concave anterior surface, its node quite high, with rounded dorsum. Postpetiole higher and wider than long, with rounded dorsum.

Spurs on the middle and hind tibiae cannot be seen in described specimen.

Dorsum of head and alitrunk with very coarse reticulation. Central part of clypeus smooth. Petiole and postpetiole smooth.

Body pilosity barely visible, but standing hairs seem to be long and sparse. Genae with suberect hairs. Scape with relatively long and sparse subdecumbent to suberect hairs. Tibiae with sparse short subdecumbent to suberect hairs. 
Total body length ca. $3.0 \mathrm{~mm}$.

MEASUREMENTS AND INDICES. AL 0.72, ESL 0.20, ESD 0.40, FW 0.16, HL 0.74, HTL 0.43, HW 0.78, OL 0.14, PnW 0.52, PPW 0.23, PPL 0.14, PW 0.17 , SL $0.53 \mathrm{~mm}$.

$\mathrm{CI}=0.95 ; \mathrm{ESLI}=0.25 ; \mathrm{ESDI}=2.07 ; \mathrm{FI}=0.20$; $\mathrm{HTI}=0.58 ; \mathrm{OI}_{1}=0.19 ; \mathrm{OI}_{2}=0.18 ; \mathrm{PI}=0.22 ; \mathrm{PPI}_{1}=$ $0.30 ; \mathrm{PPI}_{2}=1.38 ; \mathrm{SI}_{1}=0.72 ; \mathrm{SI}_{2}=0.68$.

ETYMOLOGY. The species is named after the well-known Russian hymenopterist and palaeontologist, Professor Alexandr Pavlovich Rasnitsyn.

TAXONOMIC POSITION. P. rasnitsyni is similar to species of $P$. punctatus group in the main diagnostic features (e.g. lack of spines on pronotum, coarse reticulate sculpture, shape of alitrunk etc.; for details see [Wang, 2003]). We do not assume that this species which is ca. 40 Ma years old belongs to that particular group, but would like to point out that it is very similar in its morphology to modern Pristomyrmex species, and we therefore cannot define it either as an ancestral or derived form of this genus.

\section{ACKNOWLEDGEMENTS}

We are sincerely grateful to Prof. Alexandr Rasnitsyn (Paleontological Institute of the Russian Academy of Sciences, Moscow, Russia), who provided material for this study. The present work was supported by the grant No. 11-04-00421 from the Russian Foundation for Basic Research and by the basic scientific programs of our institutions.

\section{References}

Bolton B., Alpert G., Ward P.S., Naskrecki P. 2006. Bolton's Catalogue of Ants of the World. Cambridge-London: Harvard University Press, CD-ROM.

Terayama M. 2009. A synopsis of the family Formicidae of Taiwan // Research Bulletin of Kanto Gakuen University. Vol.17. P.81-266.

Wang M. 2003. A monographic revision of the ant genus Pristomyrmex // Bulletin of the Museum of Comparative Zoology. Vol.157. No.6. P.383-542.

Zettel H. 2006. On the ants of the Philippine Islands: 1. The genus Pristomyrmex Mayr, 1866 // Myrmecologische Nachrichten. Bd.8. S.59-68. 